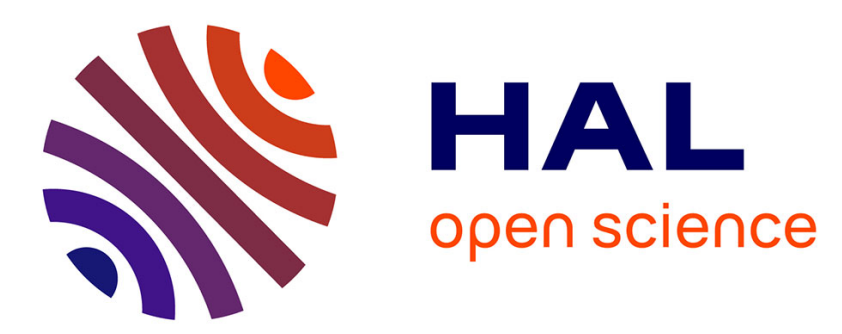

\title{
Effect of oxides and nitrates of lead on the sintering and densification of hydroxyapatite adsorbents
}

\author{
Ange Nzihou, Benu Adhikari
}

\section{To cite this version:}

Ange Nzihou, Benu Adhikari. Effect of oxides and nitrates of lead on the sintering and densification of hydroxyapatite adsorbents. Industrial and engineering chemistry research, 2004, 43 (13), p.3325-3335. 10.1021/ie030645i . hal-01634400

\section{HAL Id: hal-01634400 https://hal.science/hal-01634400}

Submitted on 1 Mar 2019

HAL is a multi-disciplinary open access archive for the deposit and dissemination of scientific research documents, whether they are published or not. The documents may come from teaching and research institutions in France or abroad, or from public or private research centers.
L'archive ouverte pluridisciplinaire HAL, est destinée au dépôt et à la diffusion de documents scientifiques de niveau recherche, publiés ou non, émanant des établissements d'enseignement et de recherche français ou étrangers, des laboratoires publics ou privés. 


\title{
Effect of Oxides and Nitrates of Lead on the Sintering and Densification of Hydroxyapatite Adsorbents
}

\author{
A. Nzihou* and B. Adhikari \\ Ecole Des Mines d'Albi-Carmaux, Centre Energétique et Environnement, LGPSD, UMR CNRS 2392, \\ Campus Jarlard, 81013 Albi Cedex 09, France
}

\begin{abstract}
The effect of lead oxide $\left(\mathrm{PbO}_{2}\right)$ and lead nitrate $\left[\mathrm{Pb}\left(\mathrm{NO}_{3}\right)_{2}\right]$ on sintering and densification of calcium hydroxyapatite (CaHAP) was studied using surface area reduction and shrinkage. The effect of concentration of these additives was studied using $2 \%$ and $10 \%(\mathrm{w} / \mathrm{w})$ mixtures. The addition of $\left(\mathrm{PbO}_{2}\right)$ and $\left[\mathrm{Pb}\left(\mathrm{NO}_{3}\right)_{2}\right]$ accelerated the surface area reduction especially when the sintering was accompanied with densification. These additives lowered the densification temperature of HAP. Much lower final densification was achieved when $10 \%$ of these additives were used. The rate of densification of pure HAP had only one peak, whereas the mixture had two or more peaks indicating that the additives bring about multiple speeds in the densification process.
\end{abstract}

\section{Introduction}

Heavy metal pollution is a major environmental concern because of the toxicity to human and plant life. This toxicity is lethal even in trace quantities and these metals have a great tendency to bioaccumulate. ${ }^{1}$

The efficiency of calcium hydroxyapatites (CaHAP) in removing bivalent heavy metals, especially lead, zinc, and cadmium, from water, wastewater, municipal solid waste incinerator (MSWI) ash, and contaminated soil has led to various studies to understand and explain the mechanisms with which it removes these pollutants. ${ }^{2-6}$ Furthermore, its suitability in in situ immobilization of these pollutants enhanced its applicability. ${ }^{7-9}$ It has been found that use of a mere $1 \%$ of HAP in contaminated soil effectively removes the lead, zinc, copper, and cadmium and that the plant growth was restored, ${ }^{8}$ and also that the use of $4 \mathrm{~g}$ of $\mathrm{HAP}$ per $\mathrm{kg}$ of soil significantly reduced the uptake of $\mathrm{Cd}$ and $\mathrm{Pb}$ by crops. ${ }^{10}$ The efficacy of solid HAP in immobilizing lead and decreasing its gastrointestinal absorption was tested in vivo in albino rats, and a $60 \%$ decrease in lead accumulation was observed without any negative effect in the calcium - phosphorus metabolism of the animal. ${ }^{11}$ The partial or complete substitution of calcium ion in CaHAP by lead ion leads to the formation of hydroxypyromorphite, the accidental presence of which in drinking water does not pose any danger as the precipitated lead is no longer bioavailable. ${ }^{11}$

The use of CaHAP in remediation of MSWI fly ashes containing heavy metals is becoming a promising technology because the classical method of solidifying MSWI fly ashes with Portland cement and subsequent landfilling has some severe limitations. These limitations include difficulty in protection against humidity and controlling the leaching of the heavy metals, ${ }^{12}$ and also that the requirement of the binder cement is relatively high. The CaHAP added externally, or formed during the reaction while the MSWI fly ash is chemically treated with a mixture of calcium hydroxide and phos-

* To whom correspondence should be addressed. Tel: +33 5634932 22. Fax: +335634930 99. E-mail: nzihou@ enstimac.fr. phoric acid maintained at a certain ratio, has been found effective in immobilizing bivalent heavy metals. ${ }^{12,13}$

A sintering step is still required even when the insoluble heavy metal-hydroxyapatite is formed. The thermal treatment process (sintering) effectively embeds the heavy metal in the hydroxyapatite matrix through densification and crystallization and also almost eliminates leaching of the heavy metals from the hydroxyapatite matrix upon subsequent landfilling. ${ }^{12-14}$ Furthermore, the ion exchange process between the calcium ion in CaHAP and the heavy metal ions is very rapid, and the external resistance to ion transfer (such as ion diffusion) basically controls the process..$^{15}$ Similarly, the surface area of the exchange or the specific surface area of the CaHAP plays an important role in determining how fast the (exchange) reaction takes place. ${ }^{16,17}$ Hence, a comparative study of the sintering and densification process of the CaHAP with the nitrates and oxides of lead is important for furthering the understanding of the immobilization behavior of the CaHAP with respect to the heavy metals. Although the sintering and densification phenomena of the CaHAP is being studied quite extensively, ${ }^{18-20}$ the effect of oxide and nitrite salts of lead on the sintering and densification of CaHAP still awaits a comprehensive study.

This paper aims to report a comprehensive study on the sintering and densification behavior of $\mathrm{CaHAP}$ along with the effect of oxides and nitrates of lead on its sintering behavior.

\section{Materials and Methods}

Lead oxide $\left(\mathrm{PbO}_{2}\right)$ and lead nitrate $\left[\mathrm{Pb}\left(\mathrm{NO}_{3}\right)_{2}\right]$ were reagent grade with $99 \%$ purity and were obtained from Aldrich and Labosie companies, respectively. They were finely ground before use. Calcium hydroxyapatite (CaHAP) was prepared by mixing calcium nitrite $\left[\mathrm{Ca}\left(\mathrm{NO}_{3}\right)_{2}\right]$ and ammoniu m hydrogen phosphate $\left[\left(\mathrm{NH}_{4}\right)_{2}-\right.$ $\mathrm{HPO}_{4}$ ] both obtained from Norskhydro. The temperature was maintained at $25^{\circ} \mathrm{C}$ and the $\mathrm{pH}$ was adjusted to $7-8$ with $10 \%$ ammonia solution according to reaction 1 . 


$$
\begin{aligned}
& 10 \mathrm{Ca}\left(\mathrm{NO}_{3}\right)_{2}+6\left(\mathrm{NH}_{4}\right)_{2} \mathrm{HPO}_{4}+8 \mathrm{NH}_{4} \mathrm{OH} \rightarrow \\
& \mathrm{Ca}_{10}\left(\mathrm{PO}_{4}\right)_{6}(\mathrm{OH})_{2}+20 \mathrm{NH}_{4} \mathrm{NO}_{3}+6 \mathrm{H}_{2} \mathrm{O}
\end{aligned}
$$

Details of the preparation and purification procedure of CaHAP powder (termed HAP henceforth) through the route of reaction 1 are given elsewhere. ${ }^{21}$ The powder was finely ground using a laboratory-scale grinder (IKA Works, Inc.) to obtain fine particles with narrow size distribution. Thermal stabilization of the powder was carried out by subjecting it to $400{ }^{\circ} \mathrm{C}$ for $2 \mathrm{~h}$. The stabilized sample exhibited agglomeration and the particle size was widely altered. Hence, the powder was ground again to obtain finer particles. This stabilized HAP powder was used throughout the study.

The structure and composition of the HAP particles was quantified by X-ray powder diffractometry (Siemens D5000). X-ray diffraction measurements (XRD) were carried out with $\mathrm{Cu} \mathrm{K} \alpha$ radiation generated at $40 \mathrm{~mA}$, $3^{\circ}<2 \theta<60^{\circ}$ range and at a scanning speed of $2^{\circ} / \mathrm{min}$. The phases present were determined by comparing the patterns with the JCPDS standards. The calcium/ phosphorus $(\mathrm{Ca} / \mathrm{P})$ ratio of the HAP was determined using atomic absorption spectrometry (Varian SepctrAA-400). This HAP was found to contain excess calcium and the $\mathrm{Ca} / \mathrm{P}$ ratio was 1.75 .

The specific surface area of the samples was determined using nitrogen adsorption with the BET method (Micrometrics Gemini Vacprep 061). The solid density of the HAP was determined by helium pycnometry (Micrometrics Accupyc 1330). The specific surface area and solid density of the HAP powder were $43.48 \mathrm{~m}^{2} / \mathrm{g}$ and $2987 \mathrm{~kg} / \mathrm{m}^{3}$, respectively.

The particle size distribution of the HAP was determined using a Malvern mastersizer (HYDRO 2000). The particles were suspended in ethanol and shaken by ultrasound. The mean particle size $[d(0.5)]$ of the HAP before the stabilization step was $5.05 \mu \mathrm{m}$, with the distribution being monomodal. However, when the stabilization step (calcination at $400{ }^{\circ} \mathrm{C}$ for $2 \mathrm{~h}$ ) was applied, the mean particle size increased. Although the stabilized powder was crushed, the mean particle size $[d(0.5)]$ remained at $23.05 \mu \mathrm{m}$ and the particle size distribution was bimodal.

The mass loss history of the samples was determined in dynamic mode using a themogravimetric analyzer (TGA-DTA, Netzsch STA 409) at a scanning rate of 10 ${ }^{\circ} \mathrm{C} / \mathrm{min}$ from room temperature to $1200{ }^{\circ} \mathrm{C}$.

Shrinkage tests of the samples were carried out by a thermomechanical analyzer (TMA, SETARAM Setsys 16/20) with 5-g constant load. The shrinkage, resulted from the rise in temperature, is defined as $\Delta L / L_{0}$, where $L_{0}$ is the initial length of the sample and $\Delta L=L_{0}-$ $L(t) . L(t)$ is the length of the sample as a function of time. The relative density of the sintered specimen is expressed as $\rho_{\mathrm{b}} / \rho_{\mathrm{s}}$, where $\rho_{\mathrm{b}}$ and $\rho_{\mathrm{s}}$ are the bulk and solid den sity, respectively. The thermomechanical analyses (dilatometry) were carried out in dynamic mode with a scanning rate of $10{ }^{\circ} \mathrm{C} / \mathrm{min}$ from room temperature to $1200{ }^{\circ} \mathrm{C}$.

Calcination experiments were carried out on a furnace (Aubry Company, France). A heating rate of $10{ }^{\circ} \mathrm{C} / \mathrm{min}$ was imposed from room temperature to the designated isotherm temperatures. The isothermal donations were maintained for 2 to $300 \mathrm{~min}$. The samples were placed on an alumina crucible and subjected to the above calcination regime under flowing air. The samples were cooled at the rate of $10{ }^{\circ} \mathrm{C} / \mathrm{min}$ to room temperature.
The heating (scanning) rate of $10{ }^{\circ} \mathrm{C} / \mathrm{min}$ was imposed for TGA and TMA, as well as for the calcination process at the furnace, in order to facilitate the comparison. The surface characteristics of the sintered agglomerate as well as the unsintered particles/aggregates was studied using environmental scanning electron microscopy (XL 30 ESEM-FEG, Phillips). The ESEM micrographs when combined with the mass loss (TGA) and the shrinkage (TMA) can provide excellent insight in to the densification process.

\section{Modeling of Sintering and Densification}

The specific surface area is one of the most reliable indicators of the sintering event because its kinetics of reduction is linked to the mechanism of the sintering, and also because it is easily and reliably measured. Various predictive models are available in the literature $22-25$ for the quantification of the specific surface area as a function of sintering temperature and time. Recently, Bailliez and Nzih ou ${ }^{21}$ compared these models and found that the Schaffler model (eq 2) better predicted the kinetics of surface area reduction of CaHAPs. Hence, the Schaffler model is used in this study.

$$
\frac{\mathrm{d} S}{\mathrm{~d} t}=-K S^{n}
$$

$S, K$, and $n$ are specific surface area $\left(\mathrm{m}^{2} / \mathrm{g}\right)$, reaction constant (1/s), and reaction order (dimensionless), respectively. Equation 2 is integrated using the specific surface area $\left(S_{\mathrm{o}}\right)$ of the stabilized HAP as given by eq 3 .

$$
S(t)=\left[S_{\mathrm{o}}^{(1-n)}+(n-1) K t\right]^{1 /(1-n)}
$$

Equation 3 was used to determine the $K$ and $n$ values using minimized function $\left(f_{\min }\right)$ represented by eq 4 .

$$
f_{\min }=\sum_{i=1}^{n}\left[S_{i}{ }^{\exp }-S_{i}^{\text {cal }}\right]^{2}
$$

$S_{i}{ }^{\exp }$ and $S_{i}{ }^{\text {cal }}$ are the experimental and calculated specific surface area, respectively.

The evolution of bulk density of the specimen as a function of temperature can be determined from the measured shrinkage history. Bulk density is an important parameter in understanding the evolution of the voidness of the specimen. This quantity is also important for following the relative density $\left(\rho_{\mathrm{b}} / \rho_{\mathrm{s}}\right)$ of the sample. The bulk density $\left(\rho_{\mathrm{b}}\right)$ can be determined using eq 5.21

$$
\rho_{\mathrm{b}}=\frac{m_{\mathrm{o}}[100-\text { weight losss }(\%)]}{\pi r^{2} L_{\mathrm{o}}[100-\operatorname{shrinkage}(\%)]}
$$

$m_{\mathrm{o}}$ and $L_{\mathrm{o}}$ are the initial mass $(\mathrm{kg})$ and initial length $(\mathrm{m})$ of the sample, and $r$ is the inner radius $(\mathrm{m})$ of the crucible in the dilatometer (TMA). Equation 5 was derived by assuming that the variation in the sample dimension is isotropic and unidirectional, and that the weight of the mass remains constant at the temperature range of interest. The validity of these assumptions will be further discussed.

\section{Results and Discussions}

4.1 Sintering and Densification of HAP. 4.1.1 Sintering. The sintering behavior of HAP was studied 


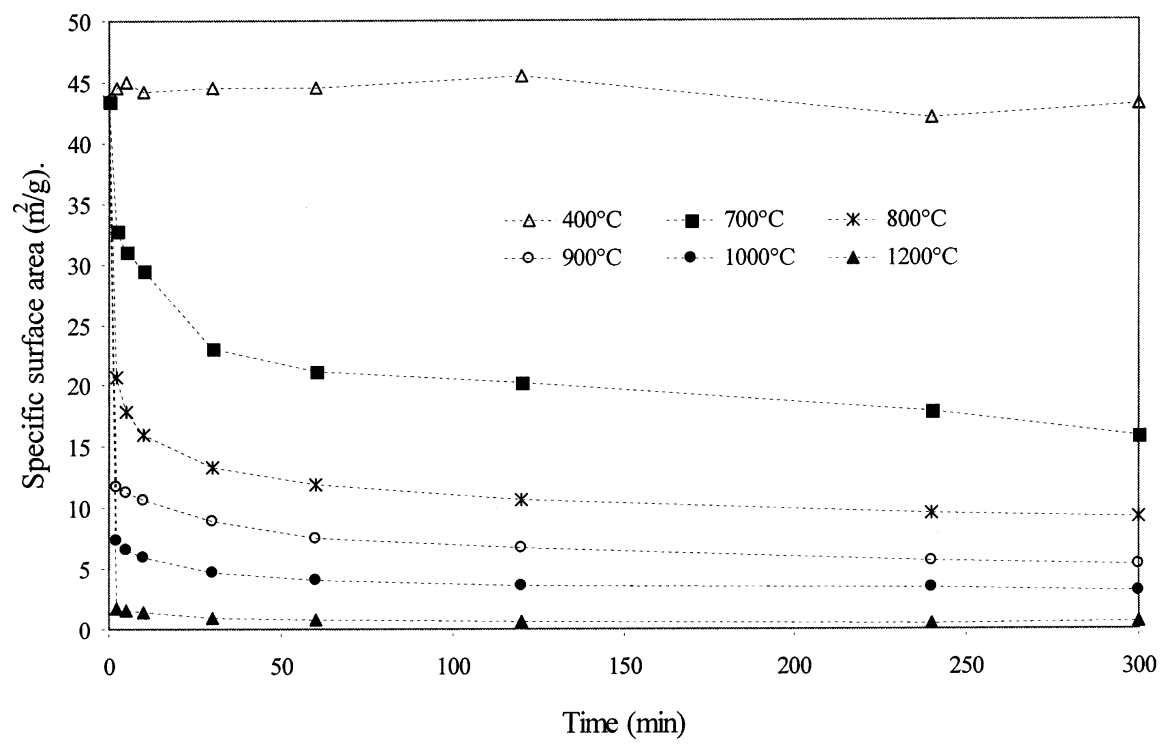

Figure 1. Kinetics of specific surface area reduction of HAP as a function of time and temperature.

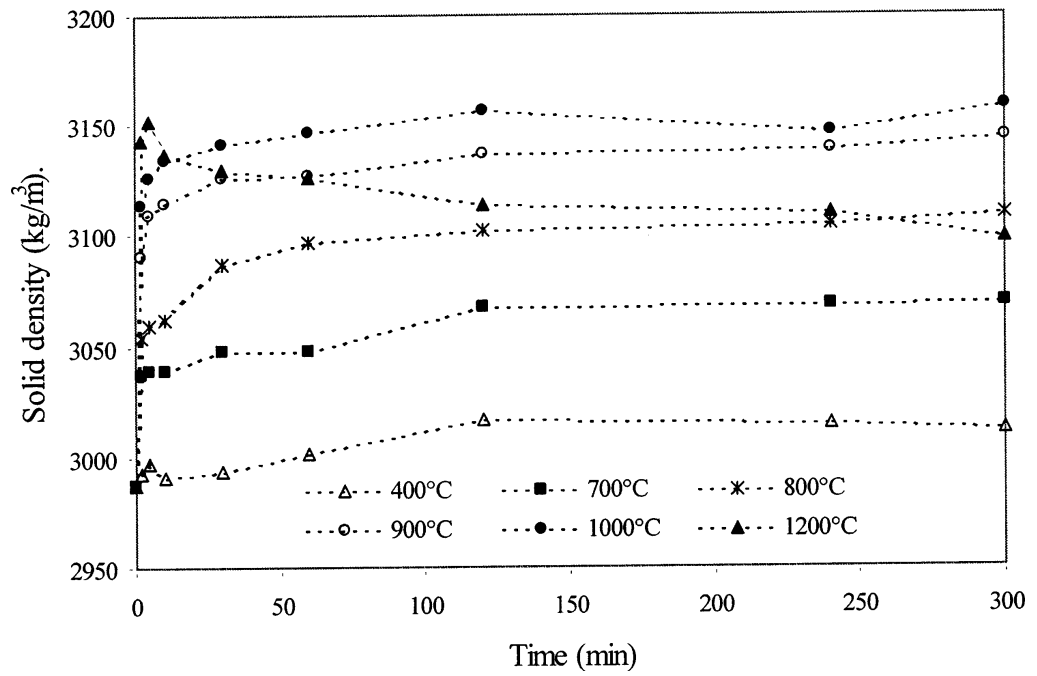

Figure 2. Variation of solid density as a function of time and temperature.

by using the specific surface area as an indicator. The kinetics of surface area reduction at different sintering temperatures is presented in Figure 1. As shown in this figure, the surface area is a strong function of temperature as well as time. For a given temperature, the surface area decreases very rapidly within the first 10 to $30 \mathrm{~min}$ and stabilizes thereafter. This figure further shows that the sintering of $\mathrm{HAP}$ at $400{ }^{\circ} \mathrm{C}$ for $5 \mathrm{~h}$ does not change the specific surface area much. At $1200{ }^{\circ} \mathrm{C}$, the surface area reduces by $97.8 \%$ and reaches $0.97 \mathrm{~m}^{2} / \mathrm{g}$ within $30 \mathrm{~min}$. Furthermore, at $1000{ }^{\circ} \mathrm{C}$ and beyond the specific surface area values at different times are very close to each other, signifying that the sintering completes almost instantly.

The effect of sintering time and temperature on the solid density of HAP powder are shown in Figure 2. It can be seen from this figure that for a given sintering temperature the solid density becomes stable within 30 min, which is similar to the effect of sintering time on the specific surface area (Figure 1). One important feature of this figure is that the solid density starts decreasing instead of increasing at $1200{ }^{\circ} \mathrm{C}$ after $10 \mathrm{~min}$. This indicates that the HAP has undergone structural change which is probably due to the partial dehydrox- ylation of HAP which leads to the formation of tetracalcium phosphate $\left[\mathrm{Ca}_{4}\left(\mathrm{PO}_{4}\right) \mathrm{O}\right.$, TTCP] and $\alpha$-tricalcium phosphate $\left[\alpha-\mathrm{Ca}_{3}\left(\mathrm{PO}_{4}\right)_{2}, \alpha-\mathrm{TCP}\right] .{ }^{26}$ This feature brings about an important effect in the sintering mechanism as will be discussed shortly. Furthermore, the maximum solid density obtained $\left(1000{ }^{\circ} \mathrm{C}, 5 \mathrm{~h}\right)$ is $3158 \mathrm{~kg} / \mathrm{m}^{3}$ which is merely $5.7 \%$ higher than the density of the unsintered sample. It can be concluded that the solid density does not change much with sintering temperature and time, and hence, it is a poor indicator of the sintering phenomenon.

4.1.2 Mechanism s of Sintering. Figure 3 presents the experimental and predicted values of specific surface area as a function of time and temperature. The predictions were carried out using eq 3 . Because the surface area does not begin to change at $400{ }^{\circ} \mathrm{C}$, the surface area values at this temperature are not used for prediction. Figure 3 shows that the predictions follow the experimental outcomes quite well. The values for $K$, which is usually known as sintering rate constant or reaction rate constant, range from $1.70 \times 10^{-14} \mathrm{~s}^{-1}$ at $700{ }^{\circ} \mathrm{C}$ to $1.3 \times 10^{-4} \mathrm{~s}^{-1}$ at $1200^{\circ} \mathrm{C}$ which means that it increases by $7.65 \times 10^{9}$ within this temperature range. On the other hand, the $n$ value, which is known 


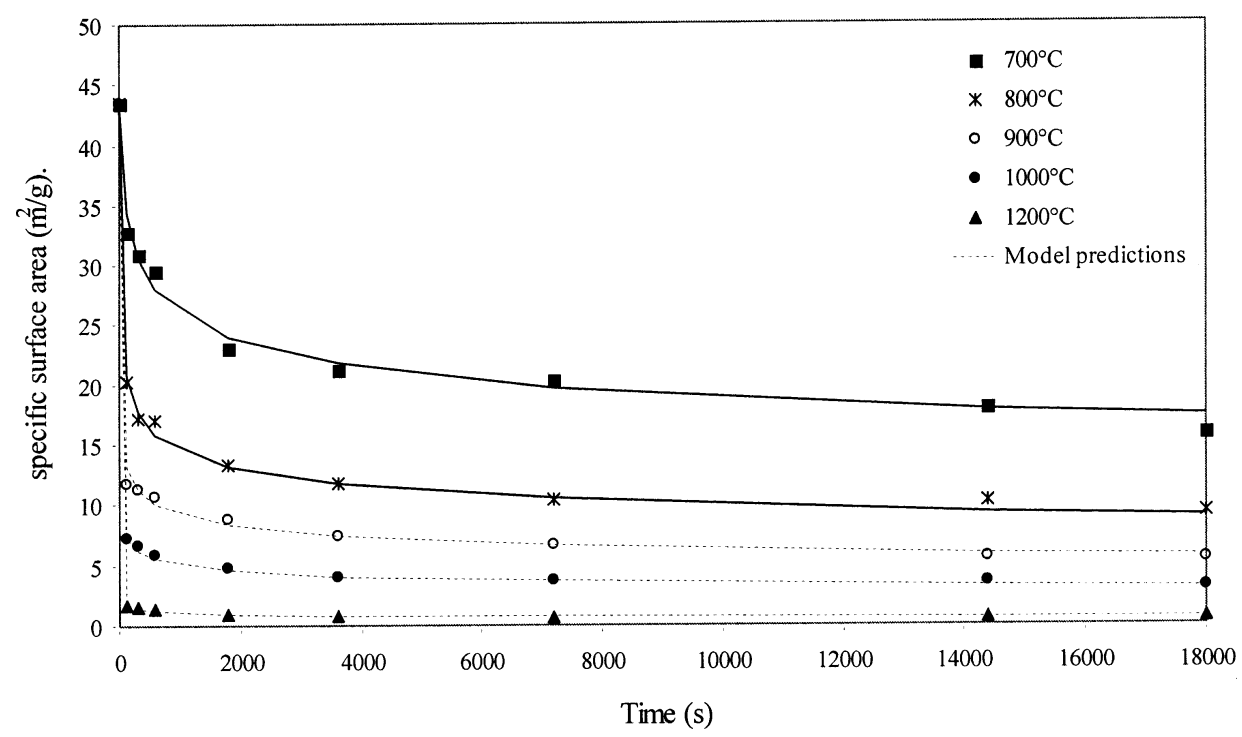

Figure 3. Reduction of specific surface area with sintering time and temperature: experimental values and predictions.

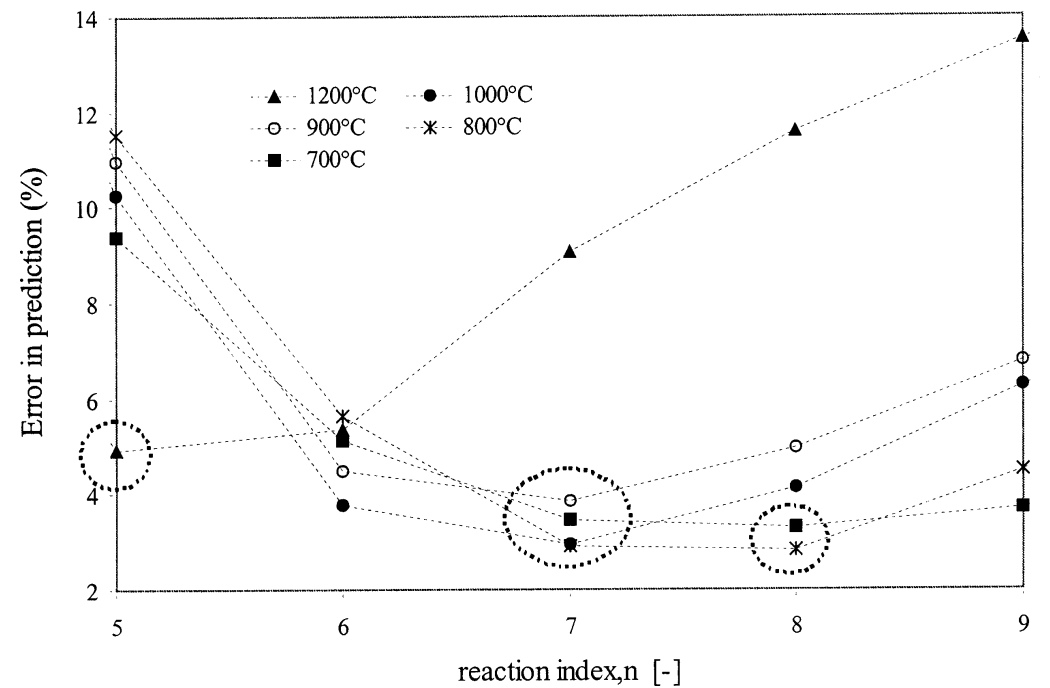

Figure 4. Variation of error in prediction with different reaction order.

as reaction order, decreases from 8 to 6 . The magnitude of $K$ value indicates pace or speed of the surface area reduction while the $n$ value indicates the more important aspect, the mechanisms involved.

Figure 4 presents the prediction error while assuming a reaction order ( $n$ value). The order of reaction varies from 5 to 8 when the sintering temperature varies from 700 to $1200{ }^{\circ} \mathrm{C}$. As will be discussed in the section dealing with densification, the densification process of HAP would not commence below $850{ }^{\circ} \mathrm{C}$, hence the reaction order below $850{ }^{\circ} \mathrm{C}$ is expected to be same as the mechanism of sintering before the commencement of densification can be, to a reasonable extent, expected to be the same. This is confirmed from Figure 4 that $n=8$ gives the minimum error in prediction. Similarly, for sintering temperature at and above $1200{ }^{\circ} \mathrm{C}, \mathrm{HAP}$ undergoes partial dehydroxylation and even the solid density gets altered (Figure 2). The rate of densification, as will be discussed later, shows that the maximum densification occurs below $1200{ }^{\circ} \mathrm{C}$. Hence, for the chemically intact HAP, it is expected that sintering at $1200{ }^{\circ} \mathrm{C}$ and above should be governed by a different mechanism. This fact is confirmed by Figure 4 where $n=5$ gives minimum error in prediction. In fact, this value $(n=5)$ may not be the sintering mechanism for chemically intact HAP, rather, it may be the sintering mechanism of partially dehydroxylated HAP, which is expected to have different physicochemical properties due to the presence of tetracalcium phosphate monoxide $\left(\mathrm{Ca}_{4} \mathrm{O}\left(\mathrm{PO}_{4}\right)_{2}\right)$ and $\alpha$-tricalcium phosphate $\left[\mathrm{Ca}_{3}\left(\mathrm{PO}_{4}\right)_{2}\right]$. The temperature range between 850 and $1200{ }^{\circ} \mathrm{C}$ is reasonably expected to be the temperature region at which the densification commences as well as completes. Hence, sintering events within this temperature range should be governed by a unique sintering mechanism. This fact is confirmed from Figure 4 in which $n=7$ gives minimum error in prediction for sintering temperature of 900 and $1000{ }^{\circ} \mathrm{C}$, and this value of $n$ is expected for $1100{ }^{\circ} \mathrm{C}$ also.

The mechanism of sintering of HAP, as evidenced by the reduction in specific surface area, can be divided into three mechanisms. First, below $850{ }^{\circ} \mathrm{C}$, the surface area reduces without densification (i.e., sintering without densification) and is represented by $n=8$. Second, at temperature range of 850 to $1200{ }^{\circ} \mathrm{C}$, the reduction in surface area is accompanied by densification process which is represented by $n=7$. Third, at temperatures at and above $1200{ }^{\circ} \mathrm{C}$, the HAP undergoes some chemi- 


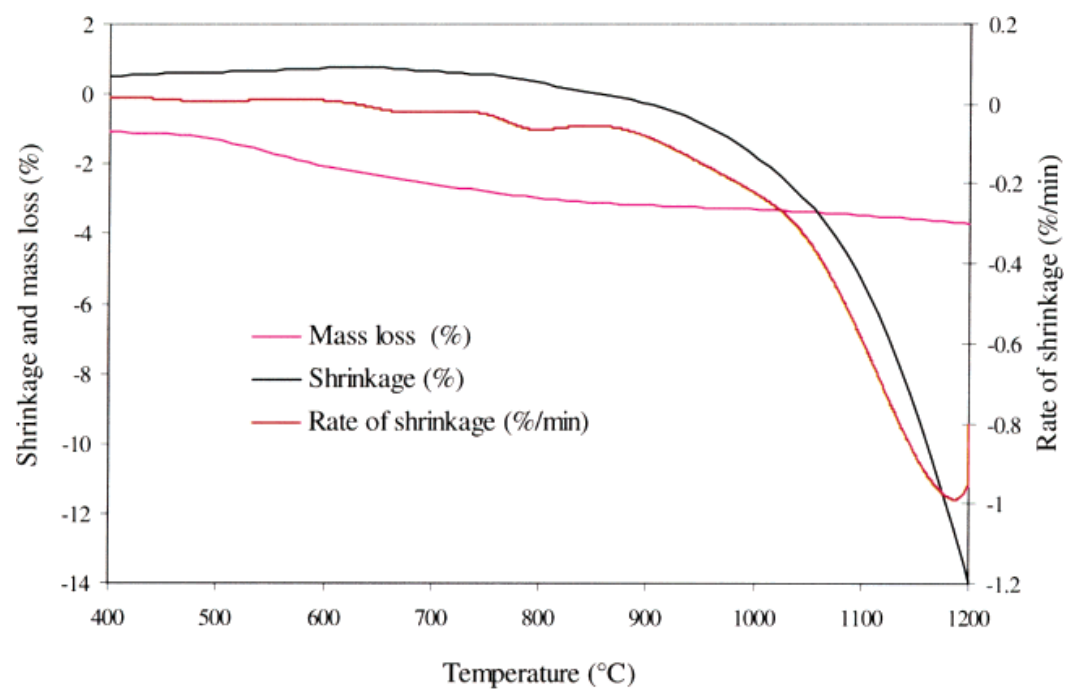

Figure 5. Plots of shrinkage $(\%)$, rate of shrinkage $(\% / \mathrm{min})$, and mass loss $(\%)$ for HAP.

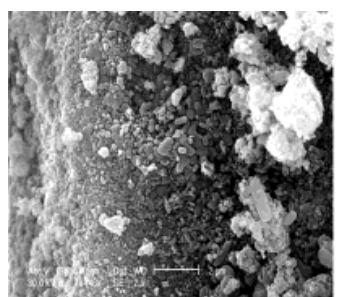

$800^{\circ} \mathrm{C}$

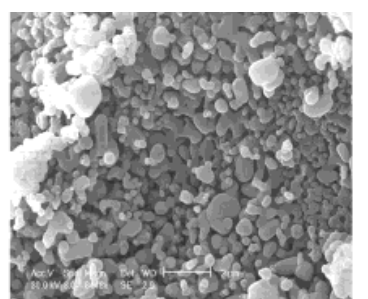

$1000^{\circ} \mathrm{C}$

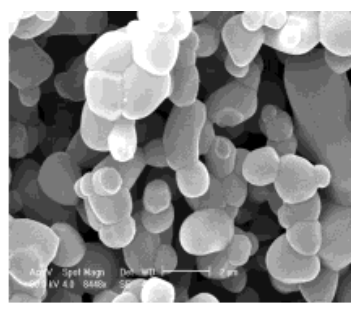

$1200^{\circ} \mathrm{C}$

Figure 6. Environmental scanning electron micrographs for HAP sintered at different temperatures for 2 h.

cal changes instantly (within $10 \mathrm{~min}$ ). The sudden decrease in the solid density of HAP while sintered at $1200{ }^{\circ} \mathrm{C}$ (Figure 2) indicates this chemical change. In fact the sintering completes at the time when HAP attains $1200{ }^{\circ} \mathrm{C}$ itself. It is expected that $n$ varies between 5 and 6 in this temperature range.

For a chemically (structurally) intact HAP, it is reasonable to state that there are two mechanisms of sintering: one that drives the reduction in the specific surface area without densification and the other that drives the reduction with densification. The "reaction order" for the former is $n=8$ while that for the latter is $n=7$. The material transport process in sintering is considered to occur due to vapor phase transport, surface migration, volume diffusion, and viscous flow. ${ }^{25}$ Considering the sintering of HAP is solid phase and that the material transport by vapor phase can be neglected, the possible driving mechanisms of the sintering can be surface migration and volume diffusion. Hence, the sintering without densification can be considered to be superficial diffusion-driven process $(n=8)$ and the sintering with densification can be considered to be driven by volume diffusion $(n=7)$.

4.1.3 Densification. The phenomen on of densification of HAP has been illustrated in Figure 5. The mass loss of HAP due to loss of absorbed or adsorbed water $(\sim 1 \%)$ usually occurs below $400{ }^{\circ} \mathrm{C}$ and is not shown here. In the temperature range where densification occurs $(>850$ $\left.{ }^{\circ} \mathrm{C}\right)$, the loss of mass is a lmost negligible $(\sim 0.5 \%)$. Hence, the densification process is due to volumetric shrinkage at a constant mass. The shrinkage commences at 850 ${ }^{\circ} \mathrm{C}$ and continues up to the temperature studied (1200 ${ }^{\circ} \mathrm{C}$ ) achieving $14 \%$ shrinkage. This fact is also manifested in environmental scanning electron microscope (ESEM) micrographs shown in Figure 6. The surface of the particles is not much compacted at $400{ }^{\circ} \mathrm{C}$ and at $800{ }^{\circ} \mathrm{C}$. The surface appears to be slightly compacted at $1000{ }^{\circ} \mathrm{C}$, whereas it is highly compacted and fused at $1200{ }^{\circ} \mathrm{C}$. This corroborates well with Figure 5, which shows that the densification process intensifies after $1000{ }^{\circ} \mathrm{C}$, and at $1200{ }^{\circ} \mathrm{C}$ a complete densification can be achieved. The rate of densification (rate of shrinkage) reveals that the maximum densification occurs below $1200{ }^{\circ} \mathrm{C}$. The variation of bulk density resulting from the densification was calculated using eq 5 and is shown in Figure 7. The bulk density first decreases and then starts increasing at a point which corresponds to the start of the densification process. However, the initial bulk density is achieved at about $1000^{\circ} \mathrm{C}$ only. The bulk density attained about $40 \%$ of the initial solid density (initial solid or theoretical density $=2987 \mathrm{~kg} / \mathrm{m}^{3}$ ) at the maximum temperature studied $\left(1200^{\circ} \mathrm{C}\right)$. This means that there is a considerable amount of voids on the sintered particle bed.

4.2 Effect of $\mathrm{PbO}_{2}$ and $\mathrm{Pb}\left(\mathrm{NO}_{3}\right)_{2}$ on Sintering and Densification of HAP. The effect of addition of $\mathrm{PbO}_{2}$ and $\mathrm{Pb}\left(\mathrm{NO}_{3}\right)_{2}$ on the sintering and densification process is discussed in this section. The aim was to understand the effect of the lead, existing in different chemical forms (oxides and nitrates), on the sintering and densification of HAP. The specific surface area of HAP with $2 \%$ additives was determined at different sintering temperatures for $2 \mathrm{~h}$. Also, a comparative presentation of the densification of HAP with $2 \%$ additives along with the pure HAP was made. The mass loss of these mixtures was not very different from the mass loss of the pure HAP, and the loss during the densification process was almost negligible ( $<1 \%$, data not shown).

Compared to HAP, the evolution of specific surface area of the mixtures showed two distinct features 


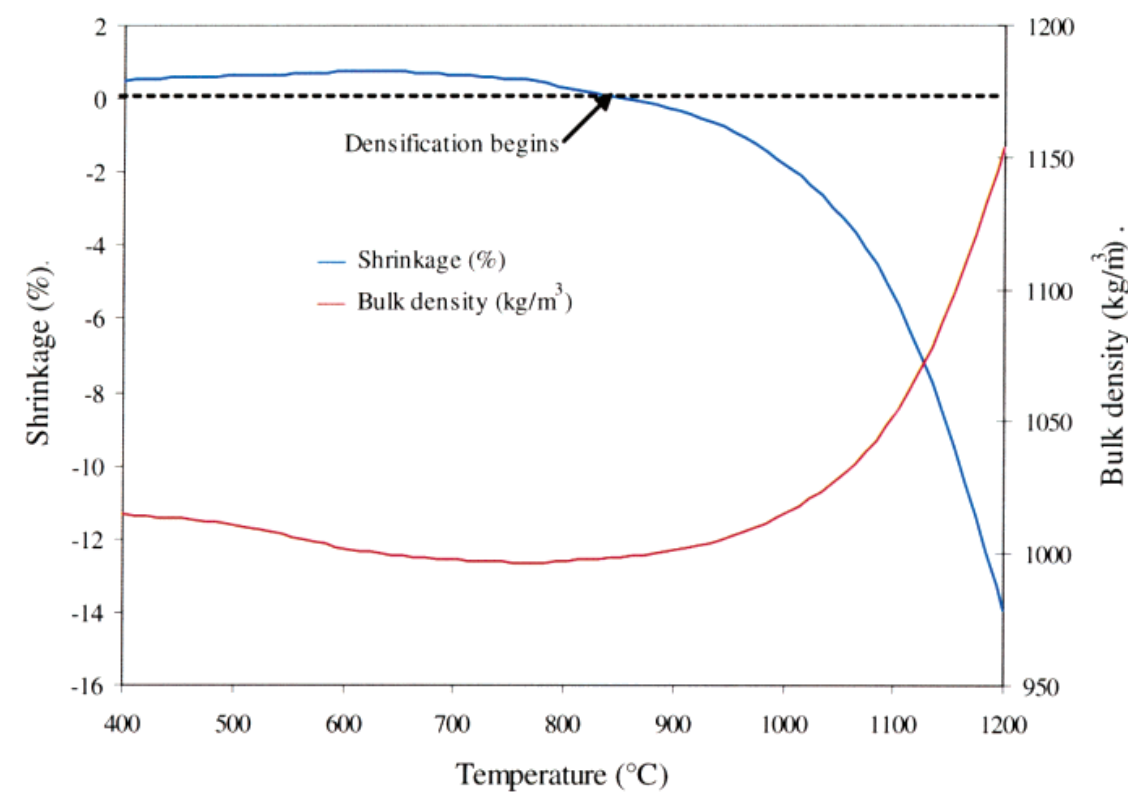

Figure 7. Variation of bulk density $\left(\mathrm{kg} / \mathrm{m}^{3}\right)$ during densification process.

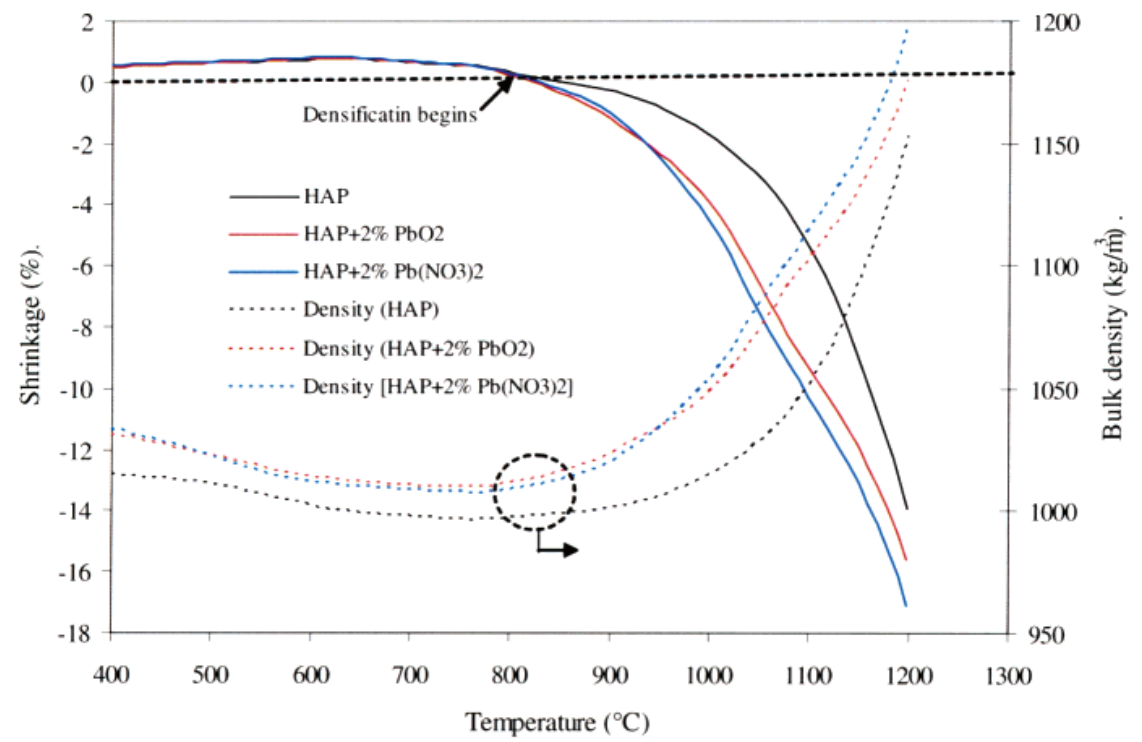

Figure 8. Variation of shrinkage (\%) and bulk density of $\mathrm{HAP}$ and its mixture with $2 \% \mathrm{PbO}_{2}$ and $\mathrm{Pb}\left(\mathrm{NO}_{3}\right)_{2}$ as a function of sintering temperature.

(Figure 11). Below $700{ }^{\circ} \mathrm{C}$, compared to pure HAP, both the mixtures had higher specific surface area. The increase of the specific surface area for $\mathrm{HAP}+2 \% \mathrm{PbO}_{2}$ and $\mathrm{HAP}+2 \% \mathrm{~Pb}\left(\mathrm{NO}_{3}\right)_{2}$ within this temperature range was $5.4 \%$ and $6 \%$, respectively. As the measurement error of the equipment was found to be of the order of $\pm 4.5 \%$, there was no significant change in the surface area due to the addition of $\mathrm{PbO}_{2}$ and $\mathrm{Pb}\left(\mathrm{NO}_{3}\right)_{2}$. The small increase in the surface area was probably brought about by the smaller particle sizes of the $\mathrm{PbO}_{2}$ and $\mathrm{Pb}$ $\left(\mathrm{NO}_{3}\right)_{2}$. The specific surface areas of the mixtures and the H AP almost coincided at $700{ }^{\circ} \mathrm{C}$ but were lower than that of HAP itself. At $800{ }^{\circ} \mathrm{C}$ and above, the specific surface areas of the mixtures were much lower than that of HAP. Up to the limit of the measurement by the equipment $\left(\sim 1 \mathrm{~m}^{2} / \mathrm{g}\right)$, the average $(\%)$ difference for mixtures with $\mathrm{PbO}_{2}$ and $\mathrm{Pb}\left(\mathrm{NO}_{3}\right)_{2}$ were 14.9 and $17.6 \%$, respectively-which is significant. These results showed that the addition of the $\mathrm{PbO}_{2}$ and $\mathrm{Pb}\left(\mathrm{NO}_{3}\right)_{2}$ in $\mathrm{HAP}$ accelerates the reduction of specific surface area at and above $800{ }^{\circ} \mathrm{C}$, a regime where sintering accompanies the den sification .

A comparative presentation of the densification of $\mathrm{HAP}$ and its mixtures with $2 \% \mathrm{PbO}_{2}$ and $\mathrm{Pb}\left(\mathrm{NO}_{3}\right)_{2}$ is made in Figure 8 . This figure shows that the densification of the both mixtures starts at about the same temperature $\left(820{ }^{\circ} \mathrm{C}\right)$, which is about $30{ }^{\circ} \mathrm{C}$ lower than the commencement of densification of pure HAP (Figure 7). The commencement of densification is represented by commencement of shrinkage, a point at which the shrinkage versus temperature plot begins to move toward negative. These additives have also brought about an increment in the extent of shrinkage. The final shrinkage (at $1200{ }^{\circ} \mathrm{C}$ ) is $15.6 \%$ and $17.1 \%$ for the mixture with $\mathrm{PbO}_{2}$ and $\mathrm{Pb}\left(\mathrm{NO}_{3}\right)_{2}$, respectively, which is $1.5 \%$ and $2.1 \%$ higher than the shrinkage of HAP. These facts are corroborated by the ESEM micrographs (Figure 9) which show that the surface of the particles has not undergone much densification or sintering up to $800{ }^{\circ} \mathrm{C}$, whereas the surface appears to be quantita- 


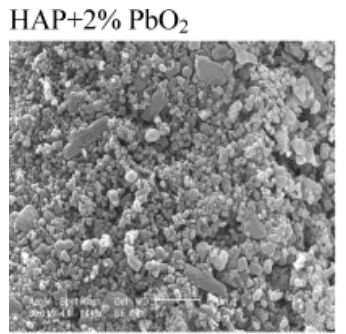

$800^{\circ} \mathrm{C}$

$\mathrm{HAP}+2 \% \mathrm{~Pb}\left(\mathrm{NO}_{3}\right)_{2}$

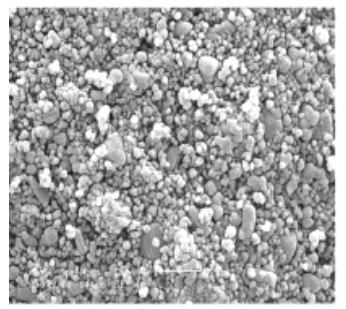

$800^{\circ} \mathrm{C}$

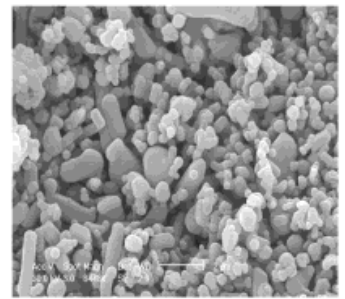

$1000^{\circ} \mathrm{C}$

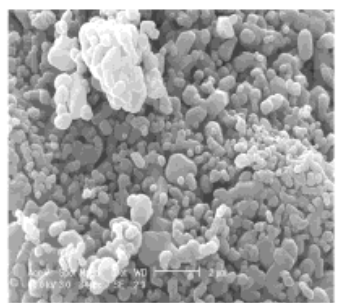

$1000^{\circ} \mathrm{C}$

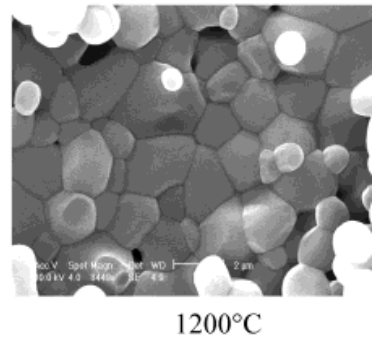

$1200^{\circ} \mathrm{C}$

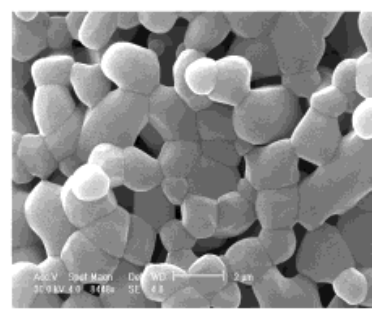

$1200^{\circ} \mathrm{C}$

Figure 9. Environmental scanning electron micrographs for $\mathrm{HAP}$ with $2 \% \mathrm{PbO}_{2}$ and $\mathrm{Pb}\left(\mathrm{NO}_{3}\right)_{2}$ sintered at different temperatures for $2 \mathrm{~h}$.

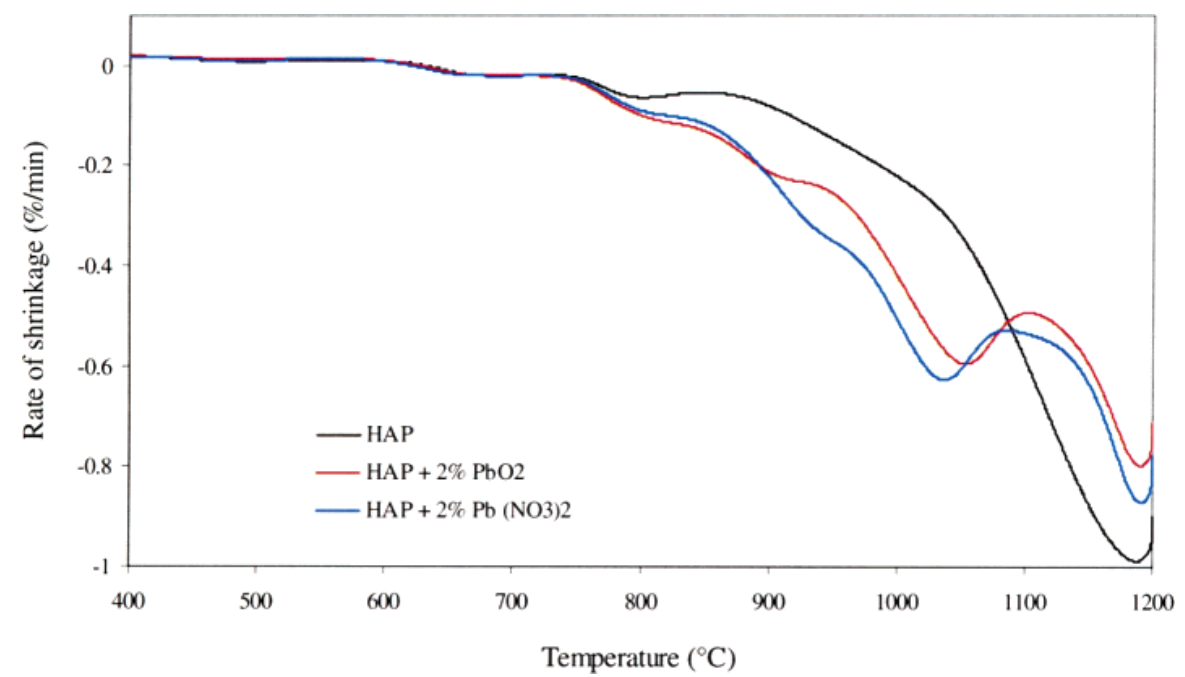

Figure 10. Variation of the rate of shrinkage $(\% / \mathrm{min})$ for $\mathrm{HAP}$ and its mixture with $2 \% \mathrm{PbO}_{2}$ and $\left.\mathrm{Pb}_{(\mathrm{NO}}\right)_{2}$ as a function of sintering temperature.

tively altered at $1000{ }^{\circ} \mathrm{C}$. At $1200{ }^{\circ} \mathrm{C}$ the surface of the mixtures appears to be completely densified and fused, and also the surfaces of these mixtures appear to be similar. When Figure 9 is compared with Figure 6, which presents the ESEM micrographs for the pure HAP, it can be seen that the surface of the samples with additives appears to be more densified and coalesced. Figure 8 also makes a comparative presentation of the increment in bulk densities of the mixtures with that of pure HAP. The bulk density of the sintered mixtures $\left(1200{ }^{\circ} \mathrm{C}\right)$ was $40 \%$ compared to the solid densities of the unsintered mixtures at room temperature. This is not significantly different from the bulk density of pure HAP (Section 4.1) at $1200{ }^{\circ} \mathrm{C}$. Hence, the densification brought about by addition of $2 \% \mathrm{PbO}_{2}$ and $\mathrm{Pb}\left(\mathrm{NO}_{3}\right)_{2}$ does not appear to be significant. However, the rate of densification could be different. The rate of shrinkage was determined by differentiating the shrinkage versus time plot with respect to time. This was then plotted against temperature to obtain shrinkage rate versus temperature plots. Figure 10 shows the the rate of densification (shrinkage) of HAP and its mixture with $2 \% \mathrm{PbO}_{2}$ and $\mathrm{Pb}\left(\mathrm{NO}_{3}\right)_{2}$ is quite different. Compared to $\mathrm{HAP}$, the rate of shrinkage of the mixtures is much faster from 800 to $1050{ }^{\circ} \mathrm{C}$, after which it declines. Furthermore, there are two peaks in the shrinkage rates of the mixtures within 1050 and $1110{ }^{\circ} \mathrm{C}$, whereas the rate of pure $\mathrm{HAP}$ shows only one peak at $1195^{\circ} \mathrm{C}$. The rate of shrinkage of mixture with $\mathrm{Pb}\left(\mathrm{NO}_{3}\right)_{2}$ is greater than that of the mixture with $\mathrm{PbO}_{2}$. This, to some extent, can be attributed to the evaporation of $\mathrm{NO}_{2}$ and greater mass loss $\left(5.6 \%\right.$ mass loss for $\mathrm{Pb}\left(\mathrm{NO}_{3}\right)_{2}$ compared to $5.3 \%$ loss for $\mathrm{PbO}_{2}$ at $1200{ }^{\circ} \mathrm{C}$ ). The more porous surface of the $\mathrm{Pb}\left(\mathrm{NO}_{3}\right)_{2}$ compared with that of $\mathrm{PbO}_{2}$ (ESEM micrographs at $1200^{\circ} \mathrm{C}$, Figure 9) suggests the evaporation of $\mathrm{NO}_{2}$. The rate of shrinkage of the HAP, as well as its mixtures, declines rapidly at the proximity of $1200{ }^{\circ} \mathrm{C}$, indicating that the sintering event completes there.

4.2.1 Effect of Concentration. How do the higher concentration $\mathrm{s}$ of $\mathrm{PbO}_{2}$ and $\mathrm{Pb}\left(\mathrm{NO}_{3}\right)_{2}$ affect the sintering and densification process of HAP? This question is 


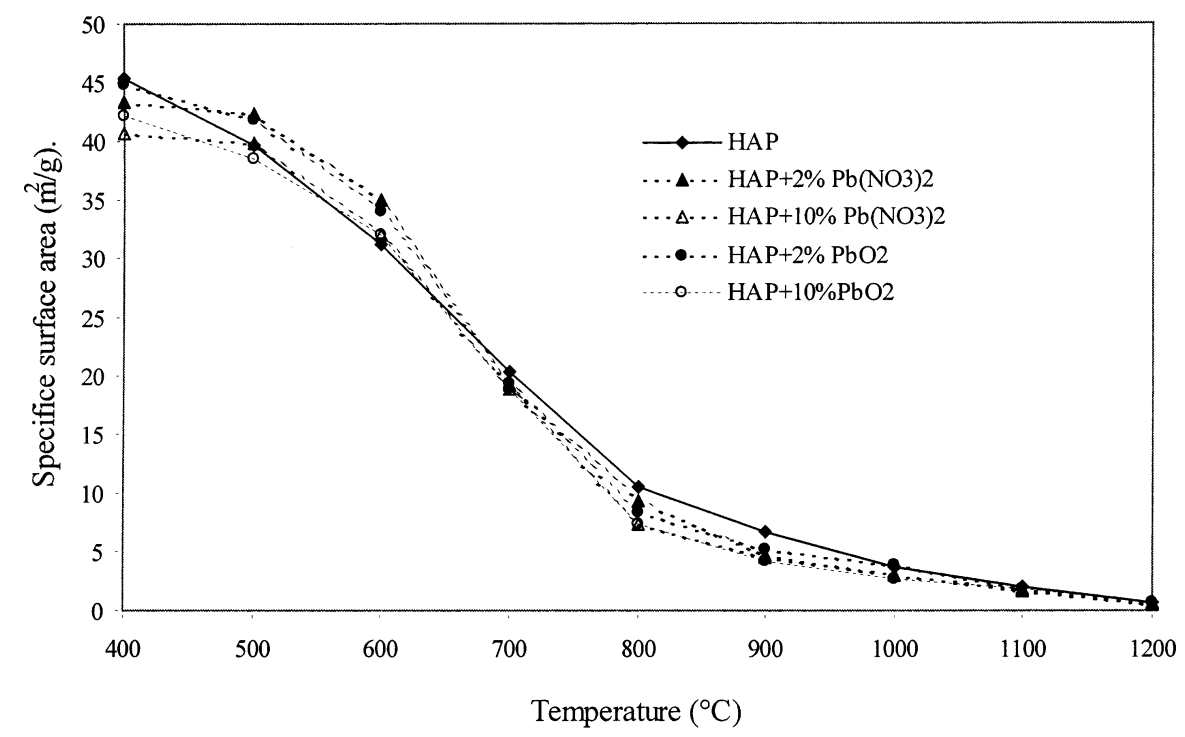

Figure 11. Effect of concentration of $\mathrm{PbO}_{2}$ and $\mathrm{Pb}\left(\mathrm{NO}_{3}\right)_{2}$ on the surface area of $\mathrm{HAP}(\operatorname{sintering~time~}=2 \mathrm{~h})$.

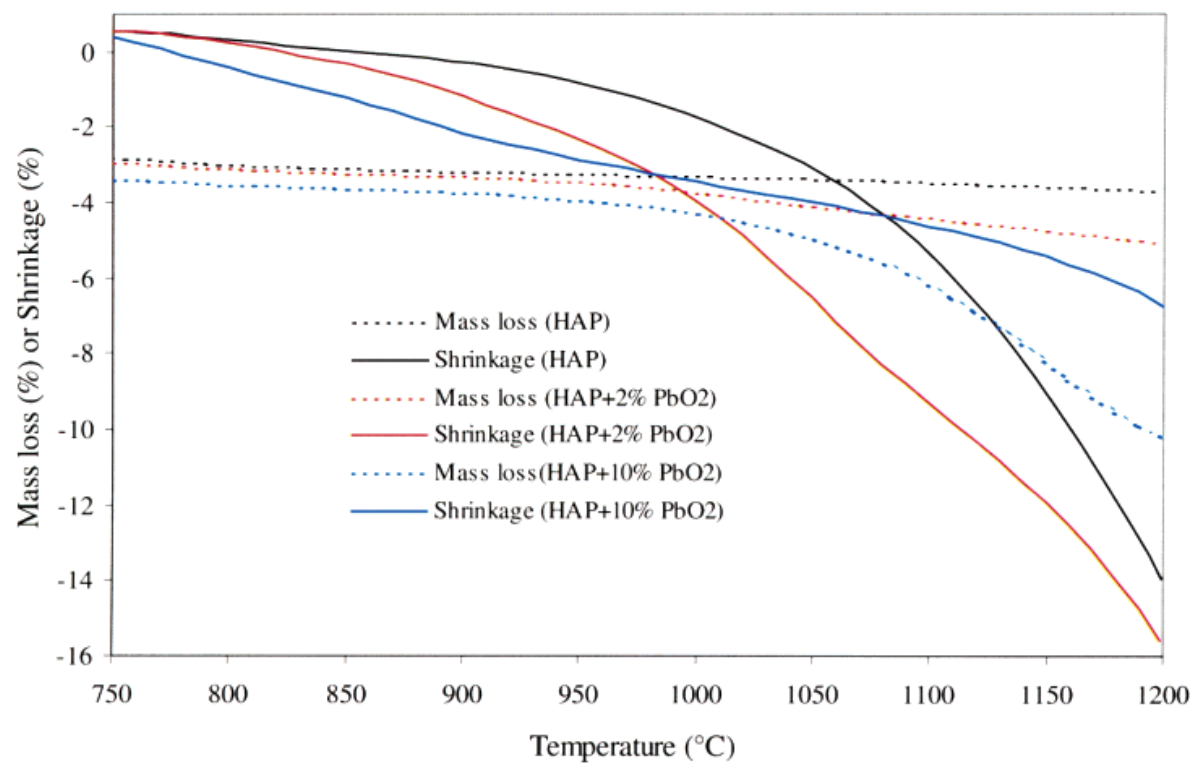

Figure 12. Effect of concentration of $\mathrm{PbO}_{2}$ on the densification and mass loss of HAP.

answered here by monitoring the specific surface area and shrinkage by increasing the amount of $\mathrm{PbO}_{2}$ and $\mathrm{Pb}\left(\mathrm{NO}_{3}\right)_{2}$ to $10 \%(\mathrm{w} / \mathrm{w})$.

4.2.2 Effect on Specific Surface Area Reduction. Figure 11 presents the specific surface area of HAP with $2 \%$ and $10 \%$ of both $\mathrm{Pb}(\mathrm{NO} 3)_{2}$ and $\mathrm{PbO}_{2}$ as a function of temperature. From this figure it can be seen that, at a given temperature, the specific surface areas of mixtures of $10 \% \mathrm{~Pb}\left(\mathrm{NO}_{3}\right)_{2}$ and $\mathrm{PbO}_{2}$ are always lower than those of their corresponding $2 \%$ mixtures. Furthermore the specific surface area reduction is significant compared to that of HAP above $800{ }^{\circ} \mathrm{C}$ where the sintering accompanies densification. The reduced specific surface areas in these mixtures below $800{ }^{\circ} \mathrm{C}$ may be due to increased particle coalescence or surface reorganization. Compared to the $2 \%$ mixtures the specific surface areas differ significantly only at $800^{\circ} \mathrm{C}$. This fact can also be observed from the ESEM micrographs (Figure 15), which show that the particles of mixture containing $10 \%$ additives are grown larger, probably due to surface diffusion. After the advancement of the densification, the specific surface areas of mixtures with $2 \%$ and $10 \%$ additives are close to each other. This signifies that the addition of merely $2 \%$ of these additives brings about close to optimum reduction in surface area of HAP.

4.2.3 Effect on Densification. Figure 12 presents the effect of concentration of $\mathrm{PbO}_{2}$ on the mass loss and densification of the HAP. This figure shows that the densification for the mixture containing $10 \% \mathrm{PbO}_{2}$ has started at $780{ }^{\circ} \mathrm{C}$ which is $70{ }^{\circ} \mathrm{C}$ and $50{ }^{\circ} \mathrm{C}$ lower than that of HAP and HAP $+2 \% \mathrm{PbO}_{2}$, respectively. This figure further shows that the rate of shrinkage of $\mathrm{HAP}+10 \% \mathrm{PbO}_{2}$ is much faster than that of both the $\mathrm{HAP}$ and $\mathrm{HAP}+2 \% \mathrm{PbO}_{2}$ up to $980^{\circ} \mathrm{C}$ then it declines substantially. At $1200{ }^{\circ} \mathrm{C}$ the final shrinkage of HAP + $10 \% \mathrm{PbO}_{2}$ is about $6.8 \%$ which is much less compared to $15.6 \%$ of $\mathrm{HAP}+2 \% \mathrm{PbO}_{2}$ and $14 \%$ that of $\mathrm{HAP}$. The mass loss of the HAP $+10 \% \mathrm{PbO}_{2}$ above $1050{ }^{\circ} \mathrm{C}$ has increased substantially (5\%) out of total loss of $10.2 \%$ (at $1200{ }^{\circ} \mathrm{C}$ ). Considering the free or adsorbed water in $\mathrm{HAP}$ is less than $1-2 \%$, the remaining $8 \%$ loss in mass might be due to partial dehydroxylation and evaporation due to chemical reaction coupled with the sintering (physical reaction) as it was described in the litera- 


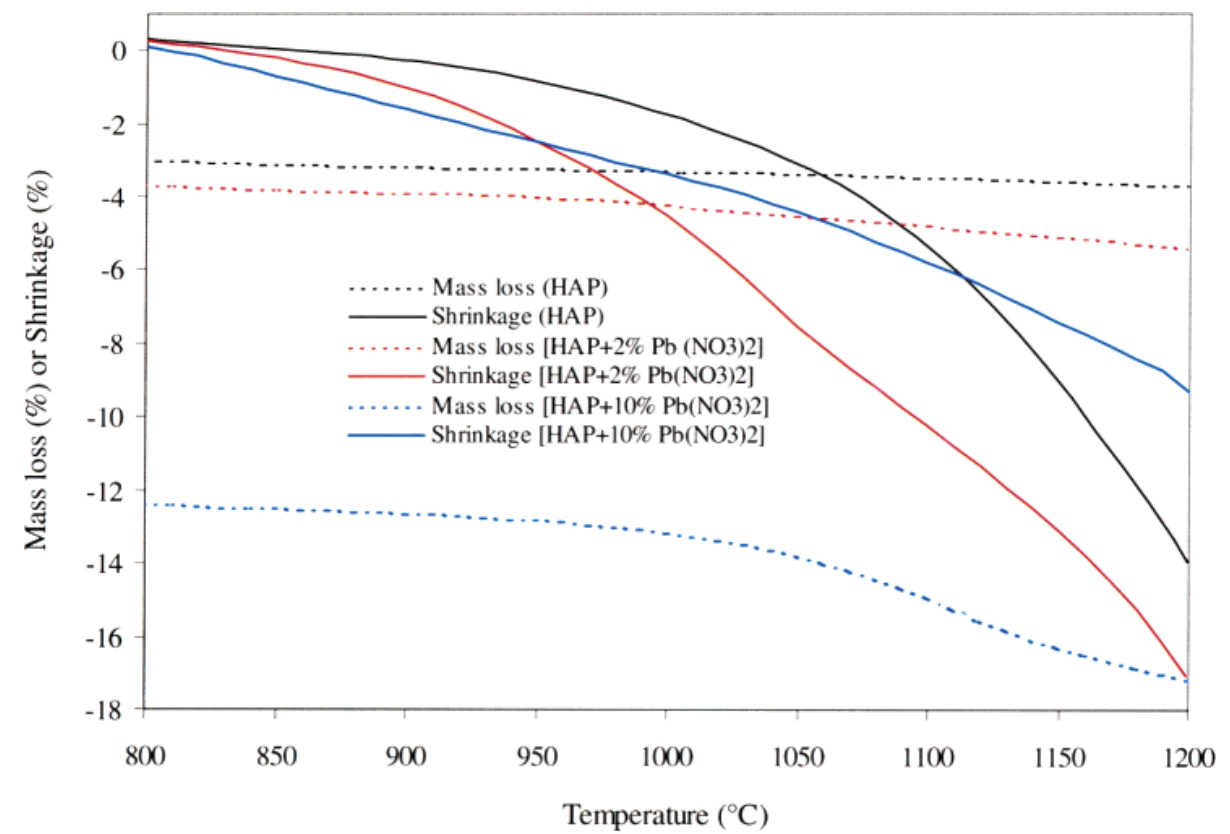

Figure 13. Effect of concentration of $\mathrm{Pb}\left(\mathrm{NO}_{3}\right)_{2}$ on the densification and mass loss of $\mathrm{HAP}$.

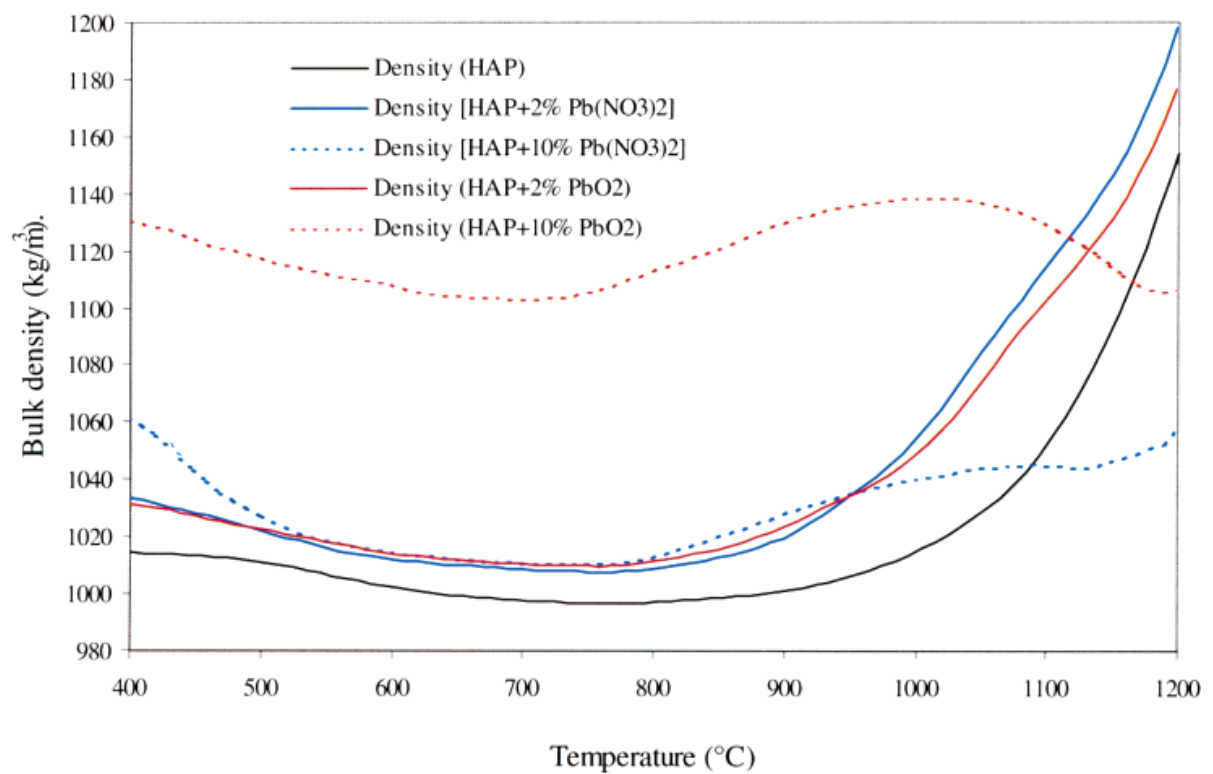

Figure 14. Evolution of bulk density of $\mathrm{HAP}, \mathrm{HAP}$ with $2 \%$ and $10 \%$ of $\mathrm{PbO}_{2}$, and $\mathrm{Pb}\left(\mathrm{NO}_{3}\right)_{2}$ as a function of temperature.

ture. ${ }^{26-29}$ The ESEM micrographs presented in Figure 15 also suggest that the particles of the mixture containing $10 \% \mathrm{PbO}_{2}$ appear to be grown larger at 800 ${ }^{\circ} \mathrm{C}$ compared to those in the $2 \%$ mixture. However, the ESEM micrographs show that the surface of mixture containing $10 \% \quad \mathrm{PbO}_{2}$ is more coalesced and fused (Figure 15) than the $2 \%$ one. This may be due to the fact that higher amounts of additives can selectively deposit on the surface, because of which the ESEM micrographs appear to be substantially coalesced.

Figure 13 presents the effect of concentration of $\mathrm{Pb}\left(\mathrm{NO}_{3}\right)_{2}$ on the mass loss and densification of HAP. This figure shows that the densification for the mixture containing $10 \% \mathrm{~Pb}\left(\mathrm{NO}_{3}\right)_{2}$ has started at $810{ }^{\circ} \mathrm{C}$ which is slightly lower than that of HAP and HAP $+2 \%$ $\mathrm{Pb}\left(\mathrm{NO}_{3}\right)_{2}$. This fact is corroborated from the ESEM micrographs (Figure 15) that the particles with 10\% $\mathrm{Pb}\left(\mathrm{NO}_{3}\right)_{2}$ are larger compared to those of $2 \%$ mixtures. Figure 13 further shows that the rate of shrinkage of
$\mathrm{HAP}+10 \% \mathrm{~Pb}\left(\mathrm{NO}_{3}\right)_{2}$ is slightly faster compared to that of $\mathrm{HAP}+2 \% \mathrm{~Pb}\left(\mathrm{NO}_{3}\right)_{2}$ up to $950{ }^{\circ} \mathrm{C}$ and then it declines substantially. At $1200^{\circ} \mathrm{C}$ the final shrinkage of HAP + $10 \% \mathrm{PbO}_{2}$ is about $9.3 \%$ which is much less compared to $17.1 \%$ of $\mathrm{HAP}+2 \% \mathrm{~Pb}\left(\mathrm{NO}_{3}\right)_{2}$ and $14 \%$ of HAP. This figure also shows that the mass loss of the HAP $+10 \%$ $\mathrm{Pb}\left(\mathrm{NO}_{3}\right)_{2}$ is very substantial compared to that of the $\mathrm{HAP}$ and $\mathrm{HAP}+2 \% \mathrm{~Pb}\left(\mathrm{NO}_{3}\right)_{2}$ under the same experimental condition. It has lost $12.3 \%$ and $17.2 \%$ mass at 800 and $1200{ }^{\circ} \mathrm{C}$, respectively. It has to be noted that this large loss of mass has not substantiated into an increased densification of the same extent. This extent of mass loss could be accorded to the evaporation of $\mathrm{NO}_{2}$ and other chemical reactions. It can also be seen that the mass loss of $\mathrm{HAP}+10 \% \mathrm{~Pb}\left(\mathrm{NO}_{3}\right)_{2}$ accelerates above $1050{ }^{\circ} \mathrm{C}$ which indicates increase in the rate of chemical reaction. It was expected that the ESEM micrographs (Figure 15) of samples containing $10 \% \mathrm{~Pb}\left(\mathrm{NO}_{3}\right)_{2}$ would be more porous that those of the samples containing $2 \%$ 


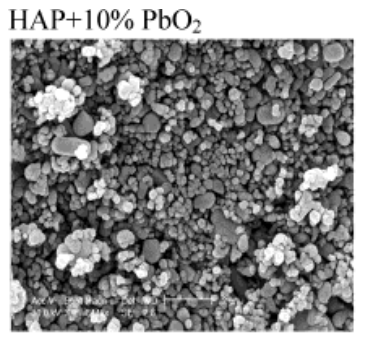

$800^{\circ} \mathrm{C}$

$\mathrm{HAP}+10 \% \mathrm{~Pb}\left(\mathrm{NO}_{3}\right)_{2}$

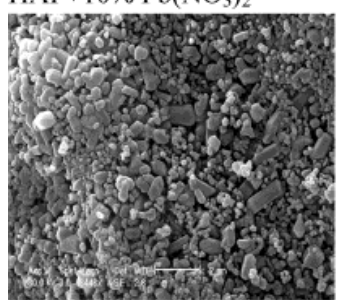

$800^{\circ} \mathrm{C}$

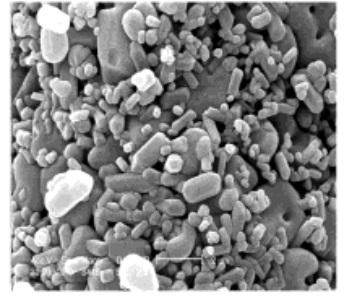

$1000^{\circ} \mathrm{C}$

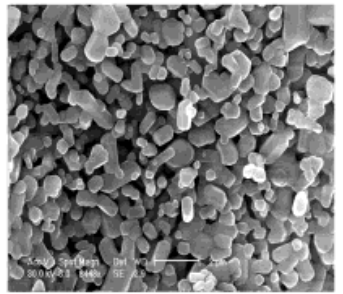

$1000^{\circ} \mathrm{C}$

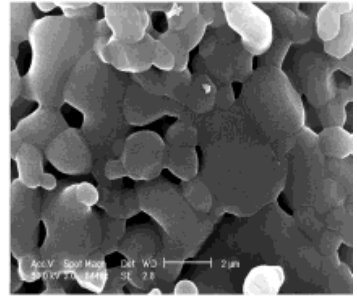

$1200^{\circ} \mathrm{C}$

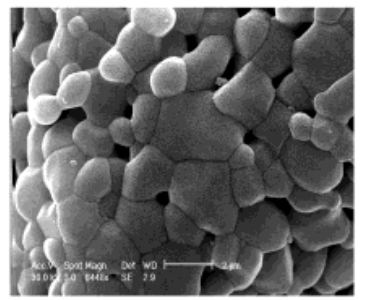

$1200^{\circ} \mathrm{C}$

Figure 15. Environmental scanning electron micrographs for $\mathrm{HAP}$ with $10 \% \mathrm{PbO}_{2}$ and $\mathrm{Pb}\left(\mathrm{NO}_{3}\right)_{2}$ sintered at different temperatures for $2 \mathrm{~h}$.

$\mathrm{Pb}\left(\mathrm{NO}_{3}\right)_{2}$ to corroborate with the mass loss kinetics. However, it seemed denser and more coalesced and fused compared with that of $\mathrm{HAP}+2 \% \mathrm{~Pb}\left(\mathrm{NO}_{3}\right)_{2}$. This may be due to the fact that the $\mathrm{Pb}\left(\mathrm{NO}_{3}\right)_{2}$ is not completely exhausted and that the unreacted $\mathrm{Pb}\left(\mathrm{NO}_{3}\right)_{2}$ is covering the surface of the HAP particles, and also that it has tendency to selectively occupy the surface of the mixture agglomerate.

Figure 14 makes a comparative presentation of the evolution of bulk density for HAP and HAP with $2 \%$ as well as $10 \% \mathrm{PbO}_{2}$ and $\mathrm{Pb}\left(\mathrm{NO}_{3}\right)_{2}$. This figure reveals that at the end of the sintering process the bulk densities of HAP with $10 \%$ additives are lower than those of their corresponding $2 \%$ mixtures. This is due to the fact that much higher mass loss and much lower densification were achieved in the mixtures with $10 \%$ additives. This figure further shows that the bulk density of HAP + $10 \% \mathrm{PbO}_{2}$ has declined after $1000{ }^{\circ} \mathrm{C}$, which is resulted from faster rate of mass loss compared to the rate of densification. This may be indicative of faster chemical reaction occurring there. At the end of sintering, the bulk densities for HAP with $10 \%$ of additives appear to be very close to their respective bulk densities at $400{ }^{\circ} \mathrm{C}$.

\section{Conclusions}

The sintering and densification behavior of $\mathrm{HAP}$ and the effect of addition of $\mathrm{PbO}_{2}$ and $\mathrm{Pb}\left(\mathrm{NO}_{3}\right)_{2}$ were studied using surface area reduction and shrinkage (densification) as indicators. The surface area reduction of the pure HAP was found to be driven by superficial and volumetric diffusion during sintering without densification and sintering with densification, respectively. Addition of $2 \% \mathrm{PbO}_{2}$ and $\mathrm{Pb}\left(\mathrm{NO}_{3}\right)_{2}$ brought about substantial surface area reduction during densification process and also lowered the temperature at which sintering with densification commenced. The higher concentration of $\mathrm{PbO}_{2}$ and $\mathrm{Pb}\left(\mathrm{NO}_{3}\right)_{2}$ failed to enhance the degree of densification process although the effect on the surface area reduction was significant. Hence, it was found that there is no straightforward correlation between surface area reduction and the volume shrinkage. The rate of densification of pure HAP had only one peak, whereas the mixture had two or more peaks indicating that the additives bring about multiple speeds in the densification process.

\section{Literature Cited}

(1) Ma, Q. Y.; Traina, S. J .; Logan, T. J .; Ryan, J . A. Effects of aqueous $\mathrm{Al}, \mathrm{Cd}, \mathrm{Cu}, \mathrm{Fe}$ (II), $\mathrm{Ni}$ and $\mathrm{Zn}$ on $\mathrm{Pb}$ immobilization by hydroxyapatite. Environ. Sci. Technol. 1994, 28, 1219.

(2) Suzuki, T.; Hatsushika, T.; Hayakawa, Y. Synthetic hydroxyapatites employed as in organic cation-exchangers.J. Chem . Soc., Faraday Trans. 1 1981, 77, 1059.

(3) Suzuki, T.; Hatsushika, T.; Miyake, M. Synthetic hydroxyapatites as inorganic cation exchangers. Part 2. J. Chem. Soc., Faraday Trans. 1 1982, 78, 3605.

(4) Suzuki, T.; Ishigaki, K.; Miyake, M. Synthetic hydroxyapatites as inorganic cation exchangers. Part 3. Exchange characteristics of lead ions $\left(\mathrm{Pb}^{2+}\right)$. J. Chem. Soc., Faraday Trans. I 1984, 80, 3157

(5) Xu, Y.; Schwartz, F. W.; Tralna, S. J . Sorption of $\mathrm{Zn}^{2+}$ and $\mathrm{Cd}^{2+}$ on hydroxyapatite surfaces. Environ.Sci.Technol. 1994,28, 1472 .

(6) Mavropoulos, E.; Rossi, A. M.; Costa, A. M.; Perez, C. A.; Moreira, J. C.; Saldanha, M. Studies on the mechanisms of lead immobilization by hydroxyapatites. Environ. Sci. Technol. 2002, $36,1625$.

(7) Ma, Q. Y.; Traina, S. J .; Logan, T. J.; Ryan, J. A. In situ lead immobilization by apatite. Environ. Sci. Technol. 1993, 27, 1803.

(8) Boisson, J.; Ruttens, A.; Mench, M.; Vangronsveld, J. Evaluation of hydroxyapatite as a metal immobilizing soil additive for the remediation of polluted soils. I. Influence of hydroxyapatite on metal exchangeability in soil, plant growth and plant metal accumulation. Environ. Pollut. 1999, 104, 225.

(9) Laperche, V.; Traina, S. J.; Gaddam, P.; Logan, T. J. Chemical and mineralogical characterizations of $\mathrm{Pb}$ in a contaminated soil: Reactions with synthetic apatite. Environ. Sci.Technol. 1996, 30, 3321

(10) Chlopecka, A.; Adriano, D. C. Influence of zeolite, apatite and $\mathrm{Fe}$-oxide on $\mathrm{Cd}$ and $\mathrm{Pb}$ uptake by crops. Sci. Total Environ. 1997, 207, 195.

(11) Arnich, N., L.; Anhers, M.-C.; Laurensot, F.; Podor, R.; Montiel, A.; Burnel, D. In vitro and in vivo studies of lead immobilization by synthetic hydroxyapatite. Environ. Pollut. 2003, 124,139 .

(12) Nzihou, A.; Sharrock, P. Calcium phosphate stabilization of fly ash with chloride extraction. Waste Manage. 2002, 22, 235.

(13) Iretskaya, S.; Nzihou, A.; Zahraoui, C.; Sharrock, P. Metal leaching from MSW fly ash before and after chemical and thermal treatments. Environ. Prog. 1999, 18, 144. 
(14) Li, X. D.; Poon, C. S.; Sun, H.; Lo, I. M. C.; Kirk, D. W. Heavy metal speciation and leaching behaviors in cement based solidified/stabilized waste materials. J. Hazard. Mater. 2001, 82, 215

(15) Takeuchi, Y.; Arai, H. Removal of coexisting $\mathrm{Pb}^{2+}, \mathrm{Cu}^{2+}$ and $\mathrm{Cd}^{2+}$ ions from water by addition of hydroxyapatite powder. J. Chem. Eng. Jpn. 1990, 21, 75.

(16) Sugiyama, S.; Ichii, T.; Matu sumoto, H.; Hayashi, H. Effect of calcination and sieving of calcium hydroxyapatite on ionexchangeability with lead cation in the presence and absence of $\mathrm{HCl}$. Adv. Environ. Res. 2002, 6, 285

(17) Da Rocha, N. C. C.; De Campos, R. C.; Rossi, A.; Moreira, E. L.; Barbosa, A. D. F.; Moure, G. T. Cadmium uptake by hydroxyapatite synthesized in different conditions and submitted to thermal treatment. Environ. Sci. Technol. 2002, 36, 1630.

(18) Ruys, A. J .; Sorrell, C. C.; Dickson, M. R.; Brandwood, A.; Milthorpe, B. K. Sintering effects on the strength of hydroxyapatite. Biomaterials 1995, 16, 409 .

(19) Juang, H. Y.; Hon, M. H. Effect of calcination on sintering of hydroxyapatite. Biomaterials 1996, 17, 2059.

(20) Nzihou, A.; Bailliez, S. Mechanisms of sintering of macroporous hydroxyapatite adsorbents. High. Temp. Mater. Proc. $\mathbf{2 0 0 2}, 21,281$.

(21) Bailliez, S.; Nzihou, A. The kinetics of surface area reduction during isothermal sintering of hydroxyapatite adsorbent. Chem. Eng.J. (in press).

(22) German, R. M.; Munir,Z. A. Surface area reduction during isothermal sintering. J. Am . Ceram. Soc. 1976, 59, 379.
(23) German, R. M. Surface area reduction kinetics during intermediate stage sintering. J. Am. Ceram. Soc. 1978, 61, 272.

(24) Nicholson, D. Variation of surface area during the thermal decomposition of solids. Trans. Faraday Soc. 1965, 61, 990.

(25) Schaffler, W. G.; Morgan, C. J.; Wilson, J. N. Aging of silica-alumina cracking catalyst. I. Kinetics of structural changes by heat and steam. J. Phys. Chem 1957, 61, 714 .

(26) Layvolle, P.; Ito, A.; Tateiohi, T. Sol-gel Synthesis of Amorphous calcium phosphate and sintering into microporous hydroxyapatite bioceramics. J Am. Ceram. Soc. 1998, 81, 1421.

(27) Van Landuyt, P.; Li, F., Keustermans, J. P.; Streydo, J. M.; Delannay, F.; Munting, E. The influence of high sintering temperatures on the mechanical properties of hydroxyapatites. $J$. Mater. Sci.: Mater. Med. 1995, 6, 8

(28) Raynaud, S.; Champion, E.; Bernache-Assolant, D. Calcium phosphate apatites with variable $\mathrm{Ca} / \mathrm{P}$ atomic ratio II. Calcination and sintering. Biomaterials 2002, 23, 1073

(29) Raynaud, S.; Champion, E.; Bernache-Assolant, D. Mechanical properties and degradation in solution of hot pressed ceramics. Biomaterials 2002, 23, 1081. 